
Ks. Grzegorz Leszczyński

Ius Matrimoniale

30 (2019) $\mathrm{nr} 4$

DOI:10.21697/im.2019.30.4.02

ORCID: 0000-0003-4189-5165

\section{Brak wiary a wykluczenie godności sakramentalnej małżeństwa}

Treść: Wstęp. 1. Intencja zawarcia małżeństwa sakramentalnego. 2. Relacja pomiędzy wiarą a ważnością zawarcia małżeństwa. 3. Wykluczenie godności sakramentalnej małżeństwa. 4. Brak wiary a wykluczenie godności sakramentalnej małżeństwa. Wnioski.

\section{Wstęp}

Wiara, zgodnie z brzmieniem Konstytucji dogmatycznej o Objawieniu Bożym Soboru Watykańskiego II, jest aktem całej osoby ludzkiej oddającej się osobowemu Bogu' ${ }^{1}$. Jest odpowiedzią człowieka na Boże Objawienie. Wiarę przyjmuje się, wyraża, przeżywa, świadczy o niej. Jakkolwiek wiara jest postawą rozumną, nie da się jej jednak sprowadzić do żadnych rozumowych racji. Wiara jest tajemnicą, zachodzącą pomiędzy Bogiem a człowiekiem, z której sam wierzący człowiek nie bardzo potrafi zdać sobie sprawę. Jest całkowicie wolnym

1 W Konstytucji dogmatycznej o Objawieniu Bożym Dei verbum czytamy m.in.: „Bogu Objawiającemu należy okazać posłuszeństwo wiary, przez które człowiek z wolnej woli cały powierza się Bogu, okazując pełną uległość rozumu i woli wobec Boga Objawiającego i dobrowolnie uznając Objawienie przez Niego dane. By móc okazać taką wiarę, trzeba mieć łaskę Bożą uprzedzającą i wspomagającą oraz pomoce wewnętrzne Ducha Świętego, który by poruszał serca i do Boga zwracał, otwierał oczy rozumu i udzielał wszystkim słodyczy w uznawaniu i dawaniu wiary prawdzie" (Konstytucja Dei verbum, p. 5). 
aktem człowieka, a jednocześnie wielkim darem ze strony Boga ${ }^{2}$. Wiara jest darem Boga, a zatem nie może być rozumiana jako pewien element życia, który można zdobyć. Więcej, to do Boga należy inicjatywa w tym, kogo obdarza On wiarą i nikogo też nie zmusza do tego, aby ją przyjął ${ }^{3}$.

Wiara człowieka jakkolwiek jest darem ze strony Boga, jest jednak postawą dynamiczną podlegającą rozwojowi. Wiary bowiem nie ma się w sposób stały i nienaruszalny. Wiara rozwija się w miarę postępowania zgodnego z sumieniem, staje się zaś formalnością, a nawet zanika, jeśli człowiek postępuje wbrew swojemu sumieniu i wbrew temu, w co wierzy ${ }^{4}$. Oznacza to, że w praktyce od człowieka samego zależy, przynajmniej na tyle, na ile jest on w stanie kierować własnym sumieniem i postępowaniem, jak kształtuje swoją wiarę, jak bardzo jest ona w nim zakorzeniona oraz czy rozwija się w nim, czy też zamiera. Nie wchodząc tutaj w dyskusję z zakresu duchowości, chcemy jedynie zaznaczyć, iż możliwy jest stan, w którym człowiek, będąc osobą ochrzczoną, utraci w praktyce swoją wiarę, tzn. rozbieżność pomiędzy autentycznym przeżywaniem przez niego wiary a czymś, co można nazwać pewnym stanem idealnym będzie tak duża, że można takiego człowieka określić terminem człowieka ochrzczonego i niewierzącego.

Możliwa jest jednak sytuacja, iż człowiek utraci wiarę niezależnie od swojej woli. Składać się może na taki stan jego ducha wiele czynników, nie zawsze zakorzenionych w nim samym. Taki właśnie stan nas interesuje, gdyż staje się on początkiem naszych rozważań dotyczących zależności między ważnością sakramentu małżeństwa a wiarą człowieka.

2 Por. A. Zuberbier, Wiara, w: A. Zuberbier (red.), Słownik teologiczny, t. II, Katowice 1989, s. 360.

3 Por. R.G. Cunningham, Marriage and the Nescient Catholic: Questions of Faith and Sacrament, Studia Canonica 15 (1981), s. 273.

4 Por. A Zuberbier, Wiara, dz. cyt., s. 361. 


\section{Intencja zawarcia małżeństwa sakramentalnego}

Kwestia intencji koniecznej do zawarcia małżeństwa sakramentalnego nie jest kwestią prostą do rozstrzygnięcia, zwłaszcza że zarówno doktryna, jak i nauczanie Kościoła zdaje się przyjmować w niektórych swoich punktach różne opcje.

Odbywający się 1980 r. Synod Biskupów zwrócił uwagę na konieczność istnienia u kontrahentów przynajmniej minimalnej intencji zawarcia małżeństwa sakramentalnego. Jak stwierdził Synod owa minimalna intencja istnieje wówczas, gdy kontrahenci proszą o celebrowanie sakramentu małżeństwa $\mathrm{z}$ powodów czysto religijnych. W przeciwnym wypadku, jeśli czynią to jedynie z przyczyn społecznych, konwencjonalnych czy zwykłej tradycji, należy wymagać od kontrahentów dowodów ich osobistej wiary, która mogłaby usprawiedliwiać złożoną przez nich prośbę dotyczącą celebracji sakramentu małżeństwa.

Tak rozumiana intencja konieczna do zawarcia małżeństwa pojawia się również u wielu autorów ${ }^{5}$ którzy nie tylko przyjmują, iż jest ona konieczna, ale w konsekwencji dochodzą do przekonania, iż słuszne byłoby określenie autonomicznego tytułu nieważności małżeństwa odnoszącego się do sytuacji, w której dane osoby nie mają minimalnej intencji zawarcia małżeństwa sakramentalnego ${ }^{6}$.

Warto w tym miejscu zwrócić szczególną uwagę na pozycję, którą prezentuje J.M. Serrano Ruiz. Określa on małżeństwo jako sakrament dojrzałości, a w konsekwencji wymagający od kontrahentów czynnego i głębokiego zaangażowania. Oznacza to, że w sytuacji, w której nie ma takiego zaangażowania ze strony kontrahentów, choćby nawet nie wykluczali oni pozy tywnym aktem woli godności

\footnotetext{
5 Por. C. Gullo, L'esclusione della sacramentalità nel matrimonio dei battezzati non credenti, Diritto di famiglia e delle persone 17 (1988), s. 738.

6 Por. H. Martiz, Ehe-Sakrament des Glaubens? Erwägungen zum Anschluß der Sakramentalität der Ehe, w: P. WESEMANN (red.), Iustus Iudex, Essen 1990, s. 256.
} 
sakramentalnej małżeństwa, można mówić o zawieraniu małżeństwa w sposób nieważny ${ }^{7}$.

Podobne zdanie wyrażają inni autorzy, którzy jakkolwiek nie mówią bezpośrednio o potrzebie wyrażenia przez kontrahentów woli zawarcia małżeństwa sakramentalnego z przyczyn czysto religijnych, niemniej wymagają od kontrahentów woli nieodrzucania doktryny Kościoła ogólnie pojętej, czy raczej przyjęcia tego, co czyni Kościół w odniesieniu do sakramentu małżeństwa, co w praktyce oznacza wewnętrzne włączenie się w myśl Kościoła ${ }^{8}$.

Tak rozumiana intencja konieczna do zawarcia małżeństwa sakramentalnego, umocniona, co podkreślamy, nauczaniem Synodu Biskupów z 1980 r., nie znajduje jednak uznania pośród większości autorów ${ }^{9}$. Większość z nich twierdzi bowiem, iż wystarczającą do zawarcia małżeństwa sakramentalnego jest intencja zawarcia małżeństwa jako takiego, a więc kontraktu, niekoniecznie w rozumieniu kontrahentów mającego swoją sakramentalną rzeczywistość ${ }^{10}$. Takie rozumowanie wydaje się uzasadnione, gdyż osoby, które pragną zawrzeć związek małżeński, a przez to wyrażają zgodę małżeńską, czyniąc to w Kościele, w rzeczy samej przyjmują, poza możliwymi wyjątkami, iż tak wyrażana zgoda małżeńska będzie miała swoją określoną przez Kościół formę $e^{11}$. Trudno byłoby raczej przyjąć, iż ktoś kto pragnie zawrzeć małżeństwo w Kościele odrzuca formę, jaka istnieje. Wydaje się, iż takie rozumowanie jest bliskie również

7 Por. Sent. coram Serrano z 1.06.1990 r., RRD 82, 1990, s. 434.

8 Por. S. Gherro, Diritto matrimoniale canonico, Padova 1985, s. 234; G. Versaldi, Exclusio sacramentalitatis matrimonii ex parte baptizatorum non credentum: error vel potius simulatio?, Periodica 79 (1990), s. 426.

9 Por. F. Bersini, I cattolici non credenti e il sacramento del matrimonio, La Civiltá Cattolica 127 (1976), s. 556; U. NAvarrete, Matrimonio, contratto e sacramento, Monitor Ecclesiasticus 118 (1993), s. 106.

10 F. BARBeri, La celebrazione del matrimonio cristiano. Il tema negli ultimi decenni della teologia cattolica, Roma 1982, s. 439.

11 Por. Z. Grocholewski, L'errore circa l'unità, indissolubilità e la sacramentalità del matrimonio, w: P.A. Bonnet, C. Gullo (red.), Errore determinans voluntatem, Città del Vaticano 1995, s. 19. 
osobom, które w praktyce są niewierzące, choć ochrzczone, gdyż zawarcie małżeństwa w kościele i dla nich wiąże się z określoną przez Kościół formą. Stąd, należy sądzić, iż intencja zawarcia małżeństwa jest wystarczająca do tego, aby pośrednio uznać istnienie w kontrahentach również intencji zawarcia małżeństwa według tego, co czyni, czy jak czyni Kościół ${ }^{12}$.

Podsumowując, zatem, należy stwierdzić, iż wystarczającą intencją zawarcia małżeństwa sakramentalnego jest intencja zawarcia małżeństwa, gdyż ta zawiera w sobie intencję zawarcia związku małżeńskiego zgodnie z tym, co czyni Kościół ${ }^{13}$. Pozostawienie jednak takiego stwierdzenia mogłoby wywołać spostrzeżenie, iż tak naprawdę religijne aspekty, które winny towarzyszyć intencji zawierania małżeństwa przez osoby ochrzczone, nie są istotne. Takie spostrzeżenie byłoby jednak nieprawdziwe, gdyż zdajemy sobie sprawę, że w kontekście wyjątkowości sakramentu małżeństwa właśnie religijna intencja jest nie tylko istotna, ale i ubogacająca związek małżeński już w samym momencie początkowym jego istnienia.

\section{Relacja pomiędzy wiarą a ważnością zawarcia małżeństwa}

Małżeństwo jest sakramentem, jeśli jest zawarte pomiędzy dwiema osobami ochrzczonymi. Czy zatem oznacza to, że tak naprawdę nie jest istotne, w jakiej dyspozycji dane osoby zawierają małżeństwo, i że w ogóle fakt praktykowania wiary nie ma jakiegokolwiek znaczenia w odniesieniu do ważności zawieranego małżeństwa? Kwestia ta w historii była zawsze problematyczną i nie zawsze jednoznacznie ujmowaną. Już w czasie Soboru Trydenckiego teologowie zastanawiali się nad znaczeniem intencji i wiary w odniesieniu do małżeństwa. I jakkolwiek nie wszyscy wskazywali na konieczność posiadania przez kontrahenta intencji zawarcia małżeństwa sakramentalnego,

\footnotetext{
12 Por. M. Mingardi, L'esclusione della dignità sacramentale del consenso matrimoniale nella dottrina e nella giurisprudenza recenti, Roma 2001, s. 198.

13 Por. A. Aвате, Il consenso matrimoniale nel nuovo Codice di Diritto Canonico, Apollinaris 59 (1986), s. 452.
} 
tak wszyscy byli zgodni co do faktu, że wiara jest elementem niezbędnym do ważnego przyjęcia każdego z siedmiu sakramentów, w tym również sakramentu małżeństwa ${ }^{14}$.

Współczesna jurysprudencja dość jednoznacznie określa sakramentalność małżeństwa w oderwaniu od faktu posiadania wiary, jak i intencji celebrowania małżeństwa sakramentalnego ${ }^{15}$. Oczywiście z punktu widzenia duszpasterskiego pogłębienie wiary winno być stawiane jako warunek zawarcia związku małżeńskiego. Co więcej, brak wiary z pewnością uniemożliwia pełne korzystanie $\mathrm{z}$ owoców sakramentu, co staje się niewątpliwym problemem duszpasterskim ${ }^{16}$. Jak bowiem stwierdza Konstytucja o liturgii świętej Sacrosanctum Concilium, nr 59: Sakramenty wiare nie tylko zakładaja, lecz za pomoca słów i rzeczy daja jej wzrost, umacniaja ja i wyrażaja. Słusznie więc nazywaja się sakramentami wiary ${ }^{17}$.

Czy jednak takie stwierdzenie konstytucji upoważnia do tego, aby sądzić, iż brak wiary po stronie kontrahenta uniemożliwia ważne zawarcie przez niego małżeństwa? Naszym zdaniem taka opinia też budzi wątpliwości.

Warto w tym miejscu odwołać się raz jeszcze do obrad Synodu Biskupów z 1980 r. oraz do propozycji ustaleń Międzynarodowej Komisji Teologicznej z 1977 r. Warto to uczynić, choć wnioski z nich wypływające nie zawsze przyjmowane są w całości na gruncie prawnym, zarówno doktryny jak i jurysprudencji.

Postulaty Komisji Teologicznej z 1977 r. koncentrowały się wokół konieczności uznania aspektu wiary jako niezbędnego do ważnego zawarcia małżeństwa ${ }^{18}$. Takie stwierdzenie Komisji budzi jednak

\footnotetext{
14 Por. M. Mingardi, L'esclusione della dignità sacramentale..., dz. cyt., s. 48.

15 Por. Sent. coram Stankiewicz z 19.05.1988 r., RRD 80, 1988, s. 324-325.

16 Por. J.F. Castaño, Il Sacramento del matrimonio, Roma 1992, s. 54, przypis 39.

17 Sacrosanctum concilium, nr 59.

18 Por. Commissione Teologica Internazionale, Propositioni su alcune questioni dottrinali, nr 2-3, w: Enchiridion Vaticanum Documenti ufficiali della S. Sede, VI, Bologna 1981-1995, s. 492. Czytamy tutaj: „Intentio requisita, nempe faciendi quod facit Christus et Ecclesia, est conditio minima, ut consensus fiat aub aspectu sacramenti verus «actus humanus». Etiamsi quaestio circa intentionem et
} 
wiele wątpliwości, przede wszystkim w kontekście poziomu wiary, który mają osoby pragnące zawrzeć małżeństwo. Wydaje się, iż taki poziom jest niemożliwy do określenia, a co najważniejsze Komisja nie daje żadnych odpowiedzi w odniesieniu do tego, w jaki sposób ów poziom wiary miałby być określony ${ }^{19}$. Co więcej, dokument nie wskazuje też, dlaczego zbyt niski poziom wiary, czy też jej brak po stronie kontrahentów miałby czynić intencję tychże kontrahentów niewystarczającą do ważnego zawarcia małżeństwa i co tak naprawdę, w konkretnej sytuacji osób pozbawionych wiary, oznacza działanie zgodnie z tym, co czyni Kościół, pozostając raczej na płaszczyźnie ogólnych tez i zasad pozbawionych rzetelnej argumentacji ${ }^{20}$. Należy zauważyć, iż postulaty zawarte w dokumencie Komisji Teologicznej z 1977 r. w praktyce oznaczają, iż osoby ochrzczone, lecz niewierzące nie mogą ważnie zawrzeć związku małżeńskiego.

Wspominany już Synod Biskupów z 1980 r., bezpośrednio nawiązując do propozycji Komisji Teologicznej z 1977 r., podkreśla istniejący ścisły związek między wiarą osoby kontrahenta i ważnością zawieranego przez niego małżeństwa sakramentalnego. Co więcej, stwierdza jednoznacznie, iż konieczna jest wiara do tego, aby kontrahent mógł ważnie zawrzeć małżeństwo, a zatem w przypadku jej braku można mówić o nieważności zawieranego małżeństwa. Synod formułuje też postulat, aby formujące się w tamtym czasie prawodawstwo uwzględniło postulat konieczności wiary w odniesieniu do ważności sakramentu ${ }^{21}$.

Z punktu widzenia czysto prawnego postanowienia zarówno Synodu Biskupów, jak i wcześniej Komisji Teologicznej nie przekonują. Wiara jako taka nie jest i nie może być warunkiem ważnego zawarcia

problema circa fidem personalem contrahentium non misceri debeant, tamen non totaliter separari possunt. Intentio vera ultimatim fide viva nascitur et nutritur".

19 Por. A. Stankiewicz, De iurisprudentia recentiore circa simulationem totalem et partialem, Roma 1996, s. 43.

20 Por. P. Delhaye, Proposizioni sulla dottrina del matrimonio cristiano. Commissione Teologica Internazionale, Civiltà Cattolica 129 (1978), t. III, s. 512-513.

${ }^{21}$ Sinodo dei Vescovi, Elenco delle proposizioni, w: Enchiridion Vaticanum. Documenti ufficiali della S. Sede, t. VII, Bologna 1981-1995, s. 714-718. 
małżeństwa. Trudno bowiem ustalić w praktyce, jaki jest poziom wiary, a zwłaszcza konkretna praktyka życia osób, które mają intencję zawarcia małżeństwa. Nie można zatem wykluczyć, iż zdarzają się sytuacje, w których dane osoby dla pewnych racji formalnych czy zewnętrznych chcą zawrzeć małżeństwo kanoniczne. To jednak nie oznacza, że wykluczają sakramentalność małżeństwa albo że nie mogą zawrzeć małżeństwo w sposób ważny. Z tego względu trudno zgodzić się z tymi autorami, którzy jednoznacznie wskazują na konieczność minimalnego poziomu wiary w odniesieniu do ważnego zawarcia małżeństwa sakramentalnego. Jednym $\mathrm{z}$ takich autorów jest D. Faltin, który tej tematyce poświęcił swoją pracę ${ }^{22}$.

D. Faltin rozpoczyna swoje rozważania od pytania, które formułuje następująco: czy do zaistnienia sakramentu wystarczy, iż kontrahenci czynią to, co Eccesia intendit, czy też konieczna jest ich osobista wiara? Nawiązując do obrad Synodu Biskupów z 1980 r., stawia następnie tezę, iż kwestia dotycząca wiary w całej swojej złożoności sprowadza się do dwóch możliwych sytuacji: albo - jak stwierdza Autor - wiara jest absolutnie konieczna i zawarcie małżeństwa sakramentalnego jej wymaga, albo nie jest konieczna i w takiej sytuacji nie bardzo można zrozumieć dlaczego się jej wymaga ${ }^{23}$.

Opierając się na teologii św. Augustyna i św. Tomasza autor słusznie uzasadnia nierozłączność kontraktu i sakramentu, wskazując, iż niezależnie od tego, czy chrześcijanie mają wiarę, czy też nie, ich związek małżeński ma charakter sakramentalny oparty na godności, którą obdarzył go Chrystus. Tak dzieje się zawsze wtedy, gdy dwie osoby ochrzczone zawierają umowę małżeńską i co najważniejsze czynią to conformia verbis et signis, czyli zgodnie z intencją faciendi id quod facit Christus et Ecclesia. W tym właśnie momencie autor ten formułuje pytanie, które zdaje się być kluczowym dla całego dalszego toku jego rozumowania. Zapytuje bowiem, czy owe słowa i znaki,

\footnotetext{
22 Por. D. FAltin, L'esclusione della sacramentalità del matrimonio con particolare riferimento al matrimonio dei battezzati non credenti, w: La simulazione del consenso matrimoniale canonico, Città del Vaticano 1990, s. 57-94.

23 Por. TAmżE, s. 67-68.
} 
wypowiadane przez osobę, która nie ma w sobie wiary, są w istocie swojej znakami i słowami pustymi, nie mającymi nic wspólnego z tym, co przez nie rozumie Kościół? Czyż nie jest prawdą, że owe znaki nabierają znaczenia jedynie w kontekście wiary i bez niej pozostają pozbawione swojej mocy ${ }^{24}$ ? Na tak postawione pytania autor odpowiada oczywiście pozytywnie, a co za tym idzie wyprowadza wniosek, iż owe znaki i słowa nabierają znaczenia jedynie w świetle wiary, dlatego też intencja zawarcia małżeństwa sakramentalnego wymaga od kontrahenta wiary ${ }^{25}$. Chociaż, co należy zauważyć, D. Faltin jednoznacznie nie formułuje tezy, iż należałoby odmówić osobom niewierzącym zawierania przez nich małżeństwa, taka teza, jak się wydaje, wynika z jego rozumowania. Autor porusza jeszcze wiele innych wątków dotyczących choćby kwestii wykluczenia godności sakramentalnej małżeństwa, nie podejmujemy jednak tej kwestii w tym momencie, gdyż stanie się ona przedmiotem naszych rozważań w rozdziale czwartym.

Tak sformułowane tezy, wskazujące jednoznacznie na konieczność przynajmniej minimalnej wiary kontrahenta w odniesieniu do ważności zawieranego przez niego małżeństwa, budzą jednak wątpliwości i zmuszają do dalszej refleksji.

Przekonujące dla nas w powyższej kwestii jest stanowisko Ojca Świętego Jana Pawła II, który w wydanej rok po Synodzie Biskupów Adhortacji apostolskiej Familiaris consortio nie podjął wniosków, do których doszedł Synod. Co więcej, zdaje się, iż zawarta w niej myśl zdecydowanie odbiega od wniosków zaproponowanych przez Synod.

W punkcie 68. Adhortacji apostolskiej Familiaris consortio Ojciec Święty stwierdza: Wiara osób proszących o ślub kościelny może mieć różny poziom i pierwszym obowiązkiem pasterzy jest dopomóc w jej odkryciu, umocnieniu i doprowadzeniu do dojrzałości. Musza oni także rozumieć racje, które skłaniaja Kościót, że dopuszcza do obrzędu także tych, których usposobienie nie jest doskonałe ${ }^{26}$. I dalej: Zatem podjęta

\footnotetext{
24 TAMŻE, s. 71.

25 TAMŻE, s. 68-71.

26 Familiaris consortio, nr 68.
} 
przez mężczyznę i kobiete decyzja zawarcia zgodnie z zamysłem Bożym małżeństwa, czyli decyzja zaangażowania przez nieodwołalna zgode małżeńską całego życia w nierozerwalnej miłości $i$ wierności bezwarunkowej, zakłada $w$ rzeczywistości, nawet jeśli w sposób nie całkiem uświadomiony, postawę głębokiego posłuszeństwa woli Bożej, ta zaś postawa nie jest możliwa bez Jego łaski $i^{27}$.

Warto zauważyć, że Ojciec Święty nie mówi w swoim dokumencie o osobach niewierzących, ile raczej o tych, których poziom wiary jest różny, a zatem, jak należy sądzić, nie zawsze wystarczający. Kluczowe w tym temacie wydaje się sformułowanie użyte przez Sobór Trydencki, który mówiąc o intencji zawarcia małżeństwa, używał terminu facere id quod facit Ecclesia ${ }^{28}$. Papież w Familiaris consortio używa terminu quod Ecclesia intendid. Kościół bowiem w przypadku sakramentu małżeństwa tak naprawdę nie czyni niczego poza ustanowieniem konkretnej formy jego zawarcia, gdyż to sami kontrahenci są szafarzami sakramentu. Kościół pozostaje niejako z boku wydarzeń, które się dokonują w momencie sprawowania sakramentu małżeństwa. Forma kanoniczna jakkolwiek wymagana jest do ważności małżeństwa, ma charakter jedynie dyscyplinarny w odniesieniu do wyrażanej zgody małżeńskiej. Forma ta ma charakter kanoniczny, nie zaś sakramentalny ${ }^{29}$. Zatem, dwie osoby, o ile tylko pragną uczynić to, co Kościół chce dopełnić, zawierają małżeństwo ważnie, niezależnie od stopnia ich osobistej wiary. Oznacza to, że zdaniem Ojca Świętego brak wiary, jako taki, nie jest i nie może być przyczyną nieważności małżeństwa, o ile tylko osoby kontrahentów pragną czynić, to co Kościół chce dopełnićs ${ }^{30}$.

Jest oczywiste, iż w sytuacji, gdy duszpasterz stwierdzi, że pragnący zawrzeć małżeństwo absolutnie odrzucają to, co Kościół chce

\footnotetext{
27 TAMŻE.

28 Sesja VII, kan. 11, Denz. 854.

29 Por. C. Burke, La sacramentalità del matrimonio: riflessioni canoniche, w: P.A. Bonnet, C. Gullo (red.) Sacramentalità e validità del matrimonio nella giurisprudenza del Tribunale della Rota Romana, Città del Vaticano 1995, s. 143-144.

30 Por. A.M. AвAте, Il matrimonio nella nuova legislazione canonica, Brescia 1985, s. 201.
} 
dopełnić, nie może dopuścić do obrzędu. Tak zresztą czytamy w cytowanej już adhortacji Jana Pawła II: [...] w przypadku, kiedy pomimo wszystkich poczynionych kroków, nowożeńcy wyraźnie i formalnie daja do zrozumienia, że odrzucaja to, co Kościót chce dopetnić, sprawujac obrzęd małżeństwa ochrzczonych, duszpasterz nie może dopuścić ich do obrzędu $u^{31}$.

Wydaje się jednak, że takie sytuacje, o których wspomina Papież są ekstremalne. W normalnych okolicznościach dwie osoby, które zgłaszają wolę zawarcia małżeństwa w kościele nie odrzucają zawarcia małżeństwa zgodnie z nauką Kościoła, niezależnie od tego jaki mają stopień wiary. Użyty w dokumencie papieskim termin co Kościół chce dopetnić, zdecydowanie lepiej brzmiący w wersji łacińskiej dokumentu "quod Ecclesia intendit” oznacza, iż nie należy wymagać od kontrahentów pragnienia zawarcia sakramentalnego małżeństwa, czyli uczynienia tego, co czyni Kościół, ale raczej zawarcia małżeństwa zgodnie z myślą Kościoła, czyli w Chrystusie. Oczywiście pozostaje pytanie, na ile dwie osoby w praktyce niewierzące pragną to uczynić w Chrystusie - jak wskazuje Ojciec Święty. Skoro jednak pragną zawrzeć małżeństwo, co więcej, pragną to uczynić zgodnie z istniejącą formą kanoniczną oraz w sposób wyraźny i formalny nie dają do zrozumienia, że odrzucają to, co Kościół chce dopełnić, wydaje się, iż taka intencja, choćby ją nazwać jedynie wyrażoną implicite, jest wystarczająca do tego, aby ich małżeństwo było można określić jako zawarte zgodnie z myślą Kościoła ${ }^{32}$. Sam zresztą Ojciec Święty nieco wcześniej stwierdza: Chęć ustalenia ostatecznych kryteriów dopuszczania do zawarcia ślubu w Kościele, które by brały pod uwage stopień wiary nowożeńców, mieści w sobie, niezależnie od wszystkiego, wielkie niebezpieczeństwa. Przede wszystkim ryzyko bezpodstawnych i dyskryminujących osądów; następnie ryzyko wywołania watpliwości co do ważności matżeństw jużzawartych, $z$ wielką szkodą dla wspólnot chrześcijańskich, oraz nowego, bezpodstawnego niepokojenia sumień

\footnotetext{
31 Familiaris consortio, nr 68.

32 Por. C. Burke, La sacramentalità del matrimonio: riflessioni canoniche..., dz. cyt., s. 145.
} 
małżonków; popadłoby się w niebezpieczeństwo kwestionowania czy też podania w watpliwość ważności sakramentalnej wielu małżeństw braci odłaczonych od pełnej komunii z Kościołem katolickim, pozostając $w$ ten sposób $w$ sprzeczności $z$ tradycją kościelna ${ }^{33}$.

Zatem, jakkolwiek wskazania Ojca Świętego mają charakter bardziej duszpasterski niż prawny, uzmysławiają jednak, iż kryterium wiary w odniesieniu do ważności zawarcia małżeństwa jest kryterium niewłaściwym, w sensie prawnym zaś - co należy podkreślić raz jeszcze - niedopuszczalnym. Związek małżeński dwojga osób ochrzczonych zawsze jest sakramentem, niezależnie od stopnia wiary i dyspozycji każdego z nich ${ }^{34}$.

Warto w tym miejscu zaznaczyć, iż wiara nie może być warunkiem ważnego zawarcia małżeństwa również ze względu na nierozdzielność natury kontraktualnej i sakramentalnej małżeństwa. Jeśli bowiem przyjmuje się, iż małżeństwo zawierane przez chrześcijan jest zarówno kontraktem, jak i sakramentem ${ }^{35}$, zatem odmówienie możliwości ważnego zawarcia sakramentu małżeństwa przez osoby nie praktykujące swojej wiary w sposób należyty oznaczałoby, iż takie osoby nie mogłyby również zawrzeć ważnie kontraktu ${ }^{36}$. Takiego zdania są oczywiście autorzy, którzy podkreślają nierozdzielność kontraktu i sakramentu w przypadku małżeństw zawieranych przez osoby ochrzczone ${ }^{37}$. Ci, którzy taką nierozdzielność negują, konsekwentnie uważają, iż osoba nie mająca wiary nie może zawrzeć ważnie

\footnotetext{
33 Familiaris consortio, nr 68.

34 Por. Z. Grocholewski, L'errore circa l'unità, indissolubilità e la sacramentalità del matrimonio, dz. cyt., s. 19.

35 Por. G. Leszczyński, Osoba ochrzczona niewierzaca a sakrament małżéstwa, Łódź 2004, wyd. II, s. 20-22.

36 Por. R. GerARDI, I problemi della determinazione della struttura ilemorfica e del ministro nel sacramento del matrimonio, Lateranum 54 (1998), s. 364.

37 Por. U. Navarrete, De vinculo matrimonii in theologia et iure canonico, w: Vinculum matrimoniale, Roma 1973, s. 138.
} 
sakramentu, a jedynie kontrakt ${ }^{38}$. Taka wizja - naszym zdaniem - jest jednak nie do pogodzenia z brzmieniem kan. $1055 \mathrm{KPK}^{39}$.

Przyjmując, zatem, tezę, iż wiara jako rzeczywistość osobowa i społeczna, ma niezwykle ważną rolę w odniesieniu do głębokiego przeżywania sakramentu i jego skuteczności w porządku łaski, w porządku jednak prawnym, tzn. w jej odniesieniu do ważności sakramentu, nie eliminuje intencji jego zawarcia w sytuacji osób niewierzących. Spróbujmy teraz zastanowić się, czy możliwe są sytuacje, w których brak wiary powoduje nieważność sakramentu małżeństwa.

\section{Wykluczenie godności sakramentalnej małżeństwa}

Odpowiedź na tak postawione pytanie nie jest łatwa, gdyż w kwestii nas interesującej autorzy nie są zgodni. Niektórzy z nich utożsamiają wykluczenie godności sakramentalnej małżeństwa $\mathrm{z}$ figurą symulacji całkowitej. Do takich autorów należą A. Abate ${ }^{40}, \mathrm{C}$. Burke ${ }^{41}$, czy też L. Vela ${ }^{42}$. Ich rozumowanie opiera się na zasadzie nierozłączności kontraktu i sakramentu, z której ich zdaniem wynika, że

\footnotetext{
38 Por. L. Orsy, Faith,Sacrament, Contract, and Christian Marriage: Disputed Questions, TS 43, 1982, s. 9-10.

39 Por. B. Zubert, Consensus sacramentalis facit nuptias?, w: W. Góralski, R. Sztychmiler (red.), Przymierze małżeńskie, Lublin 1993, s. 16-17. Autor stwierdza: „Sakramentalność jest więc według normy kodeksowej niezależna od wiary nupturientów i to tak dalece, iż zwykły błąd co do sakramentalnej godności małżeństwa nie narusza zgody małżeńskiej, chyba że determinuje wolę (kan. 1099). Jedynie wykluczenie tego istotnego elementu małżeństwa pozytywnym aktem woli ma znaczenie prawne - małżeństwo w ogóle nie dochodzi do skutku (kan. 1101 \$2). Takie rozumienie podstaw sakramentalności związku małżeńskiego ponownie znalazło się w krzyżowym ogniu krytyki. Koncepcji tej zarzuca się m. in. pewien automatyzm sakramentalny nie uwzględniający personalnej wiary nupturientów, wynikający ze statycznej wizji człowieka oraz nie liczący się ze współczesną antropologią ani psychologią".

40 Por. A. АвAте, Il matrimonio nella nuova legislazione canonica..., dz. cyt., s. 67.

41 Por. C. Burke, La sacramentalità del matrimonio: riflessioni canoniche..., dz. cyt., s. 146-147.

42 Por. L. Vela, dz. cyt., s. 998.
} 
wykluczenie sakramentalności małżeństwa koniecznie musi oznaczać wykluczenie małżeństwa jako takiego. Taka teza, co należy podkreślić, a co zauważa W. Góralski, była przeważająca zwłaszcza w okresie obowiązywalności Kodeksu Prawa Kanonicznego z 1917 r. Rzecznicy tej tezy opierali się na przesłance, iż ten kto nie chce sakramentu, a jednocześnie chce zawrzeć umowę małżeńską, w rzeczywistości nie może wykluczyć owej wartości duchowej, ponieważ kontraktu małżeńskiego zawieranego pomiędzy osobami ochrzczonymi nie da się oddzielić od sakramentu, gdyż godność sakramentalna jest nierozdzielna od kontraktu. Co więcej, w myśl tych opinii intencja stron nie zależy od kontrahentów, lecz jest $\mathrm{z}$ ustanowienia Bożego ${ }^{43}$.

Uznając zasadę, o której mowa, co nie budzi dziś żadnych wątpliwości, naszym zdaniem z punktu widzenia psychologicznego możliwe jest dokonanie rozróżnienia między pragnieniem zawarcia małżeństwa jako kontraktu a jego wykluczeniem co do jego godności sakramentalnej $^{44}$. Oznacza to, że jakkolwiek każdy kontrakt zawierany przez ochrzczonych staje się sakramentem opartym na woli Chrystusa, to jednak w pewnych sytuacjach konkretnych możliwe jest, że kontrahent nie będzie chciał zawarcia małżeństwa sakramentalnego, wykluczając wprost jego godność sakramentalną do tego stopnia, że wolałby w ogóle nie zawierać małżeństwa, gdyby ono miało mieć charakter sakramentalny. Oczywiście w konkretnym przypadku decyduje tzw. intencja przeważająca, o czym jeszcze powiemy, której skutkiem kontrahent tak zdecydowanie wyklucza sakrament, że gotowy jest nawet nie pójść do ołtarza, jeśli małżeństwo miałoby być sakramentem $^{45}$.

Należy ponadto zauważyć, iż założenie nierozłączności kontraktu i sakramentu nie może prowadzić do pewnego rodzaju automatyzmu,

\footnotetext{
43 Por. W. Góralski, Kanoniczna zgoda małżeńska, Gdańsk 1991, s. 162-163.

44 Por. F. Bersini, Il diritto matrimoniale canonico, Torino 1994, s. 126.

45 Por. P.M. Gajda, Prawo małżeńskie Kościoła katolickiego, Tarnów 2000, s. $149-150$.
} 
całkowicie oderwanego od woli stron, która przecież stanowi przyczynę sprawczą umowy małżeńskiej ${ }^{46}$.

Wielu autorów umieszcza wykluczenie godności sakramentalnej jako jedną z form symulacji częściowej, polegającą na wykluczeniu istotnego przymiotu małżeństwa. Do tychże autorów zaliczają się np. Z. Grocholewski ${ }^{47}$, F. Bersini ${ }^{48}$, czy też P.A. Bonnet ${ }^{49}$. Ich argumentacja $\mathrm{w}$ gruncie rzeczy sprowadza się do umiejscowienia godności sakramentalnej małżeństwa obok dwóch wskazanych przez Kodeks Prawa Kanonicznego w kan. 1056 przymiotów małżeństwa, w normie zawartej w kan. 1099 KPK dotyczącej błędu prawnego. Trzeba w tym miejscu jednak zauważyć, że wspomniani autorzy nie nazywają godności sakramentalnej przymiotem małżeństwa, ile raczej przyrównują ją do tychże przymiotów w kontekście kan. 1099 KPK. Jest to oczywiste, gdyż przymioty małżeństwa, jakimi są jedność i nierozerwalność, są jednoznacznie określone w kan. 1056 KPK, a w związku z tym nazwanie godności sakramentalnej małżeństwa przymiotem nie jest możliwe. Samo tylko umiejscowienie tejże godności obok dwóch przymiotów małżeństwa w kan. 1099 KPK nie jest dowodem, iż Prawodawca rozumie godność sakramentalną jako przymiot małżeństwa. Jakkolwiek godność sakramentalna małżeństwa nie jest jednym z przymiotów małżeństwa, niemniej jednak może być przyrównana do przymiotów małżeństwa w kontekście kan. $1101 \S 2$ KPK, co czynią wspomniani autorzy, wtedy jednak powstaje pytanie, czy skoro godność małżeńską można jedynie przyrównać do przymiotów małżeństwa, to nie jest ona raczej jednym z elementów małżeństwa, o których mówi wspomniany już kan. $1101 \$ 2$ KPK. Naszym zdaniem odpowiedź powinna być pozytywna.

\footnotetext{
46 Por. W. Góralski, Kanoniczna zgoda, dz. cyt., s. 163.

47 Por. Z. Grocholewski, L'errore circa l'unità, indissolubilità e la sacramentalità del matrimonio..., dz. cyt., s. 21.

48 Por. F. Bersini, Il diritto, dz. cyt., s. 126.

49 Por. P.A. Bonnet, Introduzione al consenso matrimoniale canonico, Milano 1985, s. 126.
} 
Takie ujęcie kwestii wykluczenia godności sakramentalnej nie jest zdaniem wyodrębnionym, gdyż większość autorów utożsamia godność sakramentalną małżeństwa $\mathrm{z}$ jednym $\mathrm{z}$ jego istotnych elementów, o których w kan. $1101 \$ 2$ KPK. Takiego zdania są, np. M.F. Pompedda ${ }^{50}$, W. Góralski ${ }^{51}$, C. Gullo ${ }^{52}$, M. Berti ${ }^{53}$, G. Versaldi $^{54}$, P. Moneta ${ }^{55}$.

W zasadzie trudno jest odpowiedzieć na pytanie, czy godność sakramentalna małżeństwa stanowi istotny element, czy też przymiot, o których mówi kan. $1101 \$ 2$ KPK. Moja argumentacja opiera się na tym, co już wcześniej wskazaliśmy, iż przymioty małżeństwa są przez Prawodawcę ściśle określone, natomiast Kodeks w żadnym miejscu nie wymienia istotnych elementów małżeństwa. Jurysprudencja jako jeden $z$ elementów małżeństwa traktuje wykluczenie dobra potomstwa. Doktryna wskazuje również, choć z licznymi oporami, ukierunkowanie na dobro małżonków ${ }^{56}$. Jestem zdania, że w tej figurze prawnej znajduje się również miejsce dla godności sakramentalnej małżeństwa, której wykluczenie pozytywnym aktem woli powoduje jego nieważność.

\footnotetext{
50 Por. M.F. Pompedda, Studi di diritto matrimoniale canonico, Milano 1993, s. 410.

51 Por. W. Góralski, Kanoniczna zgoda, dz. cyt., s. 164.

52 Por. C. Gullo, L'esclusione della sacramentalità nel matrimonio dei battezzati non credenti, DFP 17, 1988, s. 731.

53 Por. M. Berti, L'esclusione della sacramentalità del matrimonio da parte dei battezzati non-credenti nella dottrina e nella giurisprudenza attuali, Dissertatio ad doctoratum, Trento 1992, s. 206.

54 Por. G. VERSALDi, Exclusio sacramentalitatis matrimonii ex parte baptizatorum non credentum: error vel potius simulatio?, Periodica 79 (1990), s. 429.

55 Por. P. Moneta, Il matrimonio, w: Il diritto nel mistero della Chiesa, t. III, Roma 1992, s. 245.
}

56 Por. G. Leszczyński, Istotny element małżeństwa jako przedmiot symulacji częściowej (kan. 1101 \$ 2 KPK), Ius Matrimoniale 12 (2007), s. 94. 


\section{Brak wiary a wykluczenie godności sakramentalnej małżeństwa}

Próbując odpowiedzieć na pytanie dotyczące zależności istniejącej między brakiem wiary kontrahenta a wykluczeniem przez niego godności sakramentalnej małżeństwa, trzeba podkreślić raz jeszcze element psychologiczny jako istotny w interpretacji powyższej kwestii. W sensie obiektywnym każde wykluczenie, o którym mówi kan. 1101 $\$ 2 \mathrm{KPK}$, powoduje nieważność małżeństwa. W sensie subiektywnym istnieje jednak zasadnicza różnica między wykluczeniem małżeństwa jako takiego a sytuacją, w której ktoś pragnie zawrzeć małżeństwo, wyklucza jednak jakiś jego istotny element czy przymiot. Godność sakramentalna małżeństwa jest jednym z elementów, który obok dobra potomstwa czy ukierunkowania na dobro małżonków może stać się przedmiotem wykluczenia. Przyczyny mogą być oczywiście różne, ale jak się wydaje konkretyzują się one przede wszystkim we współczesnym, często nieobcym wielu ludziom sposobie widzenia małżeństwa. Nie tylko błędne opinie, uporczywość, ale przede wszystkim chęć nieutożsamiania się z tym, co czyni Kościół, może stać się przyczyną, która powoduje wykluczenie godności sakramentalnej małżeństwa. Nie przypadkiem Ojciec Święty w Adhortacji apostolskiej Familiaris consortio wskazywał, że w sytuacji jasnych postaw przeciwnych nauczaniu Kościoła należałoby raczej odmówić takim osobom zawarcia przez nich małżeństwa sakramentalnego. W takich bowiem okolicznościach, jak się wydaje, sama rzeczywistość wykluczenia godności sakramentalnej małżeństwa jest bliższa niż w sytuacji, w której takich wątpliwości mieć nie można. Pozostaje jednak pytanie, czy sam brak wiary jako taki jest jednoznaczny z wykluczeniem godności sakramentalnej małżeństwa, czy też owo wykluczenie jest rzeczywistością niezależną od tego, czy ktoś ma minimalny stopień wiary czy nie?

Jestem zdania, że jakkolwiek wiara kontrahenta, o czym już pisaliśmy, ma swój ogromny walor duchowy w kontekście skuteczności sakramentu małżeństwa w porządku łaski, to jednak utożsamienie samego braku wiary, powstałego z jakichkolwiek powodów 
z nieważnością zgody małżeńskiej nie jest możliwe. Uważam również, iż mogą istnieć sytuacje, w których postawa kontrahenta jest na tyle sprzeczna $\mathrm{z}$ wizją małżeństwa Kościoła, że należy odmówić udzielenia sakramentu małżeństwa takim osobom. W przypadku jednak symulacji małżeństwa kan. $1101 \$ 2$ KPK wyraźnie wskazuje, o czym pisaliśmy wcześniej, na pozytywny akt woli jako niezbędny do uznania działania osoby zawierającej małżeństwo jako symulowane. Właśnie to wyrażenie użyte w kanonie wydaje się niezwykle istotne w interpretacji pojęcia symulacji. Nie wystarcza zatem jedynie akt negatywny czy domniemany, ale konieczny jest pozytywny akt woli wykluczający.

Wydaje się, iż w naszym przypadku osoba, która deklaruje się jako niewierząca lub w praktyce pozostaje daleka od praktykowania wiary, pragnie zawarcia małżeństwa i czyni to zgodnie z tym, co dopełnia Kościół. Zatem nie można mówić o symulacji małżeństwa, gdyż nie mamy do czynienia z podstawowym jej elementem, a mianowicie pozytywnym aktem woli wykluczającym małżeństwo jako takie. Dopiero w sytuacji przeciwnej, gdy okoliczności, samo przyznanie się kontrahenta czy inne dowody bezpośrednie lub pośrednie potwierdzą jego działanie symulowane, można stwierdzić nieważność małżeństwa. Wydaje się nam, iż takie podejście jest też dowodem pozytywnego myślenia o człowieku, który z natury pozostaje szczery w swoich intencjach, którym na zewnątrz odpowiada wyrażana przez niego zgoda małżeńska. Symulacja jest wyjątkiem od reguły, uznającej zgodność woli oraz wyrażanych na zewnątrz słów i znaków.

\section{Wnioski}

Brak wiary po stronie kontrahenta, jest poważnym problemem duszpasterskim i wymaga głębokiej analizy teologicznej. Niemniej w odniesieniu do ważności małżeństwa sakramentalnego nie decyduje o tym, czy jest ono zawarte ważnie, czy też nie. Nie można bowiem wymagać od kontrahentów, aby mieli intencję zawarcia małżeństwa sakramentalnego, gdyż wystarczającą jest intencja zawarcia małżeństwa, pod warunkiem, że pragną je zawrzeć zgodnie z tym, 
co czyni Kościół. Oznacza to, że dopóki istnieje przesłanka ku temu, aby sądzić, że kontrahenci zawierają małżeństwo zgodnie z kanoniczną wizją małżeństwa, nie ma podstaw, aby odmawiać komuś jego zawarcia.

Problemem jest natomiast sytuacja, gdy duszpasterz dostrzeże, że intencja zawarcia małżeństwa, która kieruje jednym czy obojgiem kontrahentów, jest sprzeczna z tym, co Kościół rozumie jako małżeństwo kanoniczne. W takich okolicznościach należy odmówić możliwości zawarcia związku małżeńskiego, zgodnie z tym, jak naucza Ojciec Święty Jan Paweł II w Adhortacji apostolskiej Familiaris consortio. Taka intencja bowiem sprzeczna z tym, co czyni Kościół, może powodować nieważność małżeństwa albo z tytułu błędu określonego w kan. 1099 KPK albo z tytułu wykluczenia godności sakramentalnej małżeństwa w myśl kan. 1101 \$ 2 KPK.

Podsumowując zatem nasze rozważania, należy stwierdzić, iż brak wiary sam w sobie, przy wszystkich jego konsekwencjach w sferze ducha, w tym również dotyczących małżeństwa, jako taki nie jest jednoznaczny z wykluczeniem godności sakramentalnej małżeństwa. Może natomiast powodować symulację wtedy, gdy dana osoba pozytywnym aktem woli wykluczy ową godność ze swojego związku małżeńskiego, do tego stopnia, że dana osoba wolałaby raczej nie zawierać małżeństwa, niż miałoby ono mieć charakter sakramentalny.

Zdaję sobie sprawę, że takie sytuacje zdarzają się rzadko, jeśli w ogóle się zdarzają, i że udowodnienie wykluczenia godności sakramentalnej małżeństwa jest bardzo trudne. Domniemanie zgodności woli wewnętrznej kontrahenta i jej zewnętrznej formy, w co należy wierzyć, jest zgodne z prawdziwym stanem rzeczy zdecydowanej większości zawieranych związków małżeńskich. Brak wiary kontrahentów pozostaje więc w praktyce, raczej kwestią duszpasterską i stawia przed duszpasterzami ciągle nowe wyzwania. 


\section{Lack of faith and the exclusion of the sacramental dignity of marriage}

\section{Summary}

The Code of Canon Law of 1983 classifies the reasons for marriage invalidity in three different categories: diriment impediments, defects in matrimonial consent and lack or defect of canon form. Among different defects in matrimonial consent, in $1101 \$ 2$, Code of Canon Law enumerates simulations. Simulation signifies that a person contracting marriage expresses marital agreement merely on the surface, excluding in reality through a positive act of the will the marriage itself, some essential elements or an essential property of marriage. The present article is an attempt of looking at the relation existing between the validity of marriage and the exclusion of the sacramental dignity, with the special consideration of the faith of the person.

Słowa kluczowe: małżeństwo, zgoda małżeńska, symulacja, godność sakramentalna, wykluczenie.

Keywords: marriage, matrimonial consent, simulation, sacramental dignity, exclusion.

\section{Nota o autorze}

Ks. Grzegorz Leszczyński - profesor zwyczajny prawa kanonicznego, kierownik Zakładu Metodologii Prawoznawstwa i Badań Interdyscyplinarnych Wydziału Prawa i Administracji Uniwersytetu Łódzkiego, Oficjał Trybunału Metropolitalnego Łódzkiego. 